\title{
LABOR MARKET IN SERBIA - THE PROBLEM OF UNDECLARED WORK
}

\author{
$\check{S}_{\text {utaković Teodora }}{ }^{1}$
}

\author{
Simović Danka²
}

\begin{abstract}
The focus of our research is the problem of undeclared work in the labor market in Serbia. We have investigated how frequent it is and what are the main reasons for it. Likewise, we have tested differences between different groups of employees and their level of undeclared work and their reasons for accepting it. The research is done based on the survey conducted in the Republic of Serbia in 2020. The obtained data from the survey was analysed by descriptive statistics, t-tests, and one-way analysis of variance (ANOVA).
\end{abstract}

Key words: labor market, undeclared work.

\section{INTRODUCTION}

The labor market in Serbia is the subject of many research. Many of them focused on gender, age, and everyday work (Bakić, 2009).

The gender gap is being examined in terms of different opportunities for women and men during the recruitment process and during work,

1 Doktorand, Ekonomski fakultet u Beogradu, Kamenička 6, 11000 Beograd, e-mail: sutteo1311@gmail.com.

2 Doktorand, Ekonomski fakultet u Beogradu, Kamenička 6, 11000 Beograd, e-mail: danka.simovic90@gmail.com. 
including job promotions. It is well known that women earn less than man, and are less likely to be promoted to higher positions than men (Goldin, 1990). This is not the case only in developing countries, but also in developed countries, as proven by many studies. As per research of Fodor and Glass (2018), the gender gap in employment varies widely across Central and Eastern Europe. Most of studies regarding gender discrimination focus on finding differences between men and women in some measurable characteristic (earnings, bonuses, etc) and to find the reasons for these differences. Many research focus on gender gap in entrepreneurship and the main causes of it (Vossenberg, 2013). If the reason for the higher income of the man in comparison to the women is not result of his higher professional and educational background for the same job position, is it likely that discrimination is to be found.

Undeclared work is everyday work that is hidden from the official Government bodies i.e. is not reported. Different terms are used for this phenomenon such as undeclared work, unregistered work, informal work, subterranean work, underground work, tealight work, hidden work, unobserved work, and illicit economy (Rennoy, 2007). The phenomenon of undeclared work is primarly being investigated in the countries of Southeast Europe. Tackling the undeclared economy representing around a quarter of Gross Domestic Product in Southeast Europe is a significant task for Southeast European governments (Schneider and Williams 2013). There is no unique definition of undeclared work. However, reflecting the consensus in the literature, undeclared work is defined as paid work that is legal in all respects other than it is not declared to the authorities for tax, social security, or labor law purposes (Williams C. and Franic J., 2015). The work of an employee can be fully reported, partly reported, or fully unreported. Undeclared work is harmful to the economy as it boosts the black economy. The main reasons employers are interested in the undeclared work of their employees are high taxes and contributions they are obligated to pay to the Government. By choosing undeclared work, these taxes remain unpaid and therefore huge losses are made for the fiscal authorities. However, finding reasons for employer's choice of undeclared work as evident, researches less focus on employee's reasons for accepting the undeclared work.

Undeclared work is a direct consequence of an agreement between employer and employeeand therefore, requires both sides. 
Our research have focused on finding out how frequent is undeclared work among employees in Serbia. Moreover, we have found out the main reasons why employees accept undeclared work. Also, we have compared different groups of employees to spot the differences betweentheir level of undeclared work and their reasons for accepting it. Groups of employees havebeen made based on different criteria such as sex, age, education level, and sector they work. The labor market in Serbia is a subject of many studies. However, different authors investigate different aspects of the labor market in Serbia. Some of the authors investigate the gender gap in the labor market in Serbia. Others are focused on regional differences in thelabor market. High taxes and everyday work are some of the main issues for employers and employees in Serbia, and likewise, it is part of the research of different authors. Reva (2012) was investigating gender inequality in the labor market in Serbia. She concluded that women in Serbia are much less likely to be employed, start a business or be successful in the political area. The author concluded that the wage gap indicates discrimination of women in the labormarket as earnings differentials cannot be explained by differences in observed characteristics of male and female employees. Kolin (2010) was also investigating gender inequalities andwomen's position in Serbia's labor market. Her study shows that women's level of education is almost equal to that of men, but still, women fail to enjoy quality jobs and successful professional careers to the same extent as men. Avlijaš, Ivanović, Vladisavljević and Vujić (2013) found that employed women in Serbia are better qualified but earn less than men - awoman with the same level of eduation and working experience as a man earns $11 \%$ less.Savković and Gajić (2016) were investigating similarities and differences between labormaket conditions in Serbia and EU countries. The authors have concluded that increasing similarity of EU countries and Serbian labour markets is evident, especially in the aftermath of the economic crisis. Blunch and Sulla (2011) researched influence of the financial crisis onwomen and men in the labor market in Serbia. Their research showed that men are more hitby the crisis in terms of unemployment, while women are more hit than men in terms of thelevel of earnings. Kostandinović and Stanković (2020) were investigating regional disproportions in the labor market in Serbia. The authors identified 
seven low-paid industrial sectors in Serbia. Likewise, these authors found a significant disproportion in wages of workers according to regions. Kogan (2011) was investigating the secondary labor market in Serbia. In her research, she pointed that the secondary labor market in Serbia is significant for young people and that employment in the second labor market is usually unregistered.

Education dropouts are caused by the attractiveness of working in the secondary labor market, while those who are educated do not find it attractive. Koettl (2012) pointed that two major issues in the Serbian labor market are high level of inactivity and a high level of informal employment. This author suggested three possible ways to decrease informal employment and to activate the inactive people: to make formal work pay off for low-wage earners, which genuinely means to test any entitlements to free health insurance or other municipal entitlements, to step up inspections, and enforcement. Williams (2016) researched holistic approach to tackling undeclared work. In his research, he stated that the holistic approach includes direct and indirect policy approaches. As per the author, direct approaches reduce the costs and increase the benefits of operating on a declared basis and increase the costs and reduce the benefits of operating undeclared. Primary, direct approaches mean to punish undeclared work and to reward declared work. On the other side, as per this research, there are indirect approaches that recognise that citizens and businesses are not just rational economic actors but social actors who engage in undeclared work when formal institutional failings lead them to adopt norms and beliefs regarding participation in undeclared work.

\section{AIM OF RESEARCH AND METHODOLOGY}

The main subject of our research is the labor market in Serbia and the problem of undeclared work. We have investigated discrimination, safety and reasons for undeclared work in the labor market in Serbia. Moreover, we have tested if there are differences between different groups of employees and their percentage of undeclared work and their reason for accepting undeclared work. Groups of employees have been divided into several groups based on criteriums: sex, age, level of education, and the sector where they work. 
The main research questions we have set in this research are:

1. How frequent is discrimination at work and during the recruitment process in Serbiaand what are the most common types of discrimination?

2. What are the main reasons why the employees in Serbia accept undeclared work?

3. Is complete safety at work provided for employees in Serbia?

The main hypothesis we have tested in our research are:

1 There are no significant differences between men and women in the level of their undeclared work stated and their reason for accepting undeclared work.

2 There are no significant differences between people with different education level in the level of their undeclared work stated and their reason for accepting undeclared work.

3 There are no significant differences between people of different age groups in the level of their undeclared work stated and their reason for accepting undeclared work.

4 There are no significant differences between people from different sectors in the level of their undeclared work stated and their reason for accepting undeclared work.

To collect data about the labor market in the Republic of Serbia, we conducted a survey in 2020. The sample was random without repetition. The target population consisted of employees in Serbia, without entrepreneurs. The research design is intersectoral. The method of data collection is via an online questionnaire. The survey contains seventeen questions. The questions in the survey are of a closed type, except for the last question, which, in addition tothe offered answers, also has the possibility of giving one's answer (combined type). The survey is anonymous. Reasons for the anonymity of the survey should be sought like issues involving private information such as undeclared work, discrimination at work, safety at work, etc. From the demographic questions, the survey contains questions about: gender, age, level of education and the sector of the economy in which the respondent works. A total number of received survey responses was 106. 
Methods that are used in the research include descriptive statistics, correlation and regression methods. We used these methods as follows:

- Descriptive statistics: to describe the main variable used in the research. We haveanswered our main research questions which are the frequence and the types of discrimination discovered among employees, reasons of accepting the undeclared work and whether the full safety at work is provided for employees in Serbia.

- t-test and ANOVA: we used t-test to see if there are significant differences between man and woman and their level of undeclared work and their reasons for accepting the undeclared work. When using age, educational level and sector where employees work at, to divide participants, we have formed more than two groups of participants. Therefore, in these cases, we have used ANOVA test to examine whether there are siginificant differences between groups of participants regarding their level of undeclared work and reasons for accepting the undeclared work.

\section{RESULTS AND DISCUSSION}

In order to answer our main research questions, we have used descriptive statistics. Our first research question was focused on discrimination frequency and the most common types of it. As per the data collected and analysed, $74.5 \%$ of participants did not experience discrimination during the recruiment process in Serbia.

Table 1. Discrimination during the recruitment process

\begin{tabular}{|c|c|c|c|c|}
\hline Valid & Frequency & Percent & Valid percent & Cumulative percent \\
\hline No & 79 & 74.5 & 74.5 & 74.5 \\
\hline Yes & 27 & 25.5 & 25.5 & 100 \\
\hline Total & 106 & 100 & 100 & \\
\hline
\end{tabular}

Source: Authors' work

However, the percentage of employees in Serbia who did not experience discrimination at work is less than the percentage of those who did not experience discrimination in recruitment process. Thus, $67 \%$ of survey participants stated that they did not experience discrimination at work, while $33 \%$ stated that they had experienced some discrimination at work. 
Table 2. Discrimination at work

\begin{tabular}{|c|c|c|c|c|}
\hline Valid & Frequency & Percent & Valid percent & Cumulative percent \\
\hline No & 71 & 67.0 & 67.0 & 67.0 \\
\hline Yes & 35 & 33.0 & 33.0 & 100.0 \\
\hline Total & 106 & 100.0 & 100.0 & \\
\hline
\end{tabular}

Source: Authors' work

Using crosstabulation, we concluded that $19 \%$ of survey participants have experienced both discriminations at work and discrimination during the recruitment process.

Table 3. Discrimination at work and discrimination at the recruitment process

\begin{tabular}{|c|c|c|c|c|}
\hline & \multicolumn{4}{|c|}{ Discrimination at work } \\
\hline \multirow{4}{*}{$\begin{array}{c}\text { Dicrimination at recruitment } \\
\text { process }\end{array}$} & & No & Yes & Total \\
\hline & No & 64 & 15 & 79 \\
\hline & Yes & 7 & 20 & 27 \\
\hline & Total & 71 & 35 & 106 \\
\hline
\end{tabular}

Source: Authors' work

Graph 1. Discrimination types

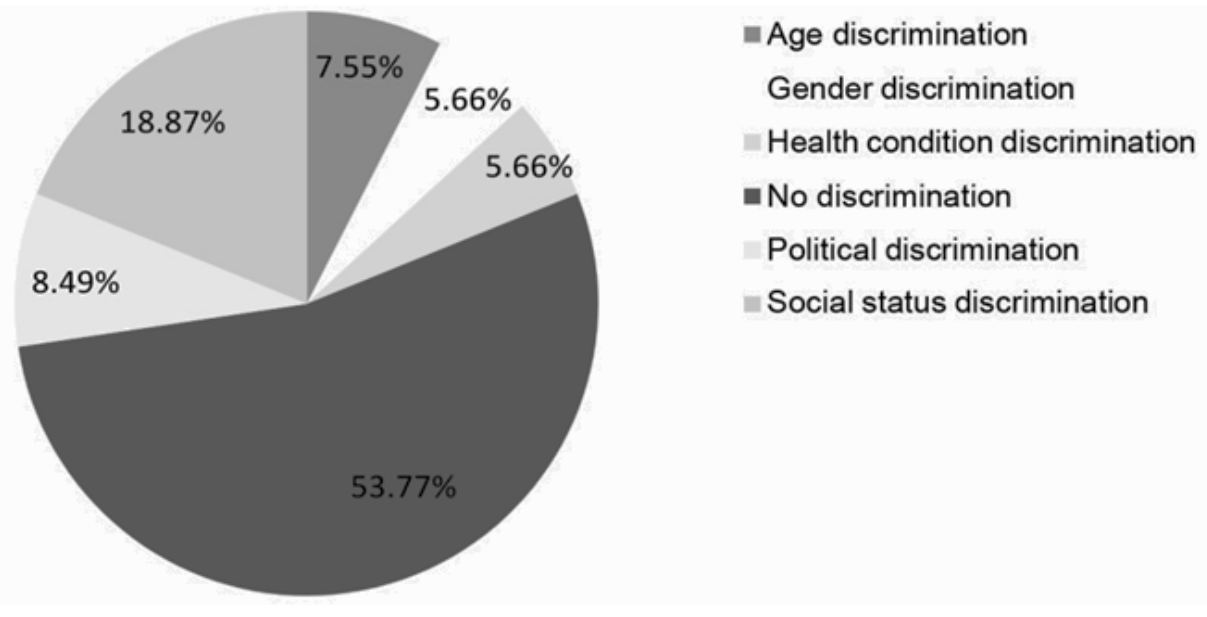

Source: Authors' work 
As per data collected, the most common type of discrimination is discrimination based on social status (18.87\%). After it, most common discrimination type is political discrimination (8.49\%).

Our second research question was focused on discovering the main reasons employees in Serbia accept undeclared work. As per analyzed data, more than half of survey participants (57.55\%) answered that the main reason for accepting the undeclared work is the high risk of unemployment. The second main reason for accepting the undeclared work in Serbia is the amount of salary (35.85\%).

Graph 2. Reasons for accepting undeclared work

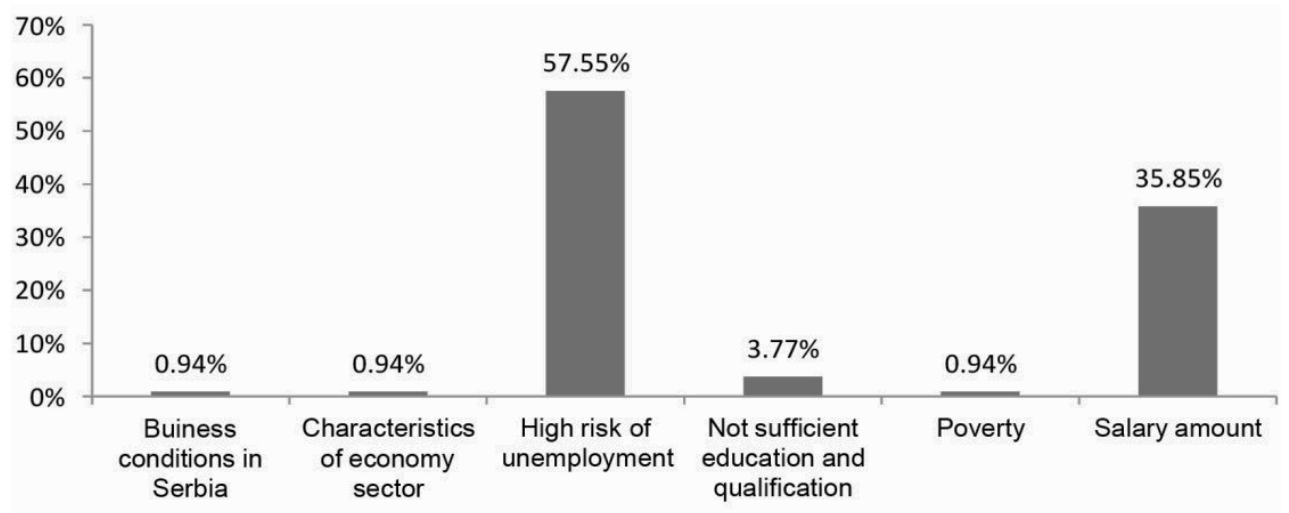

Source: Authors' work

Our last research question concerned safety at work for the employees in Serbia. Half of the survey participants responded that full safety is provided at their work. However, $40.57 \%$ of participants have responded that only partly safety is provided at their work, while $8.49 \%$ of participants claim they do not have any safety at work. 
Graph 3. Safety at work

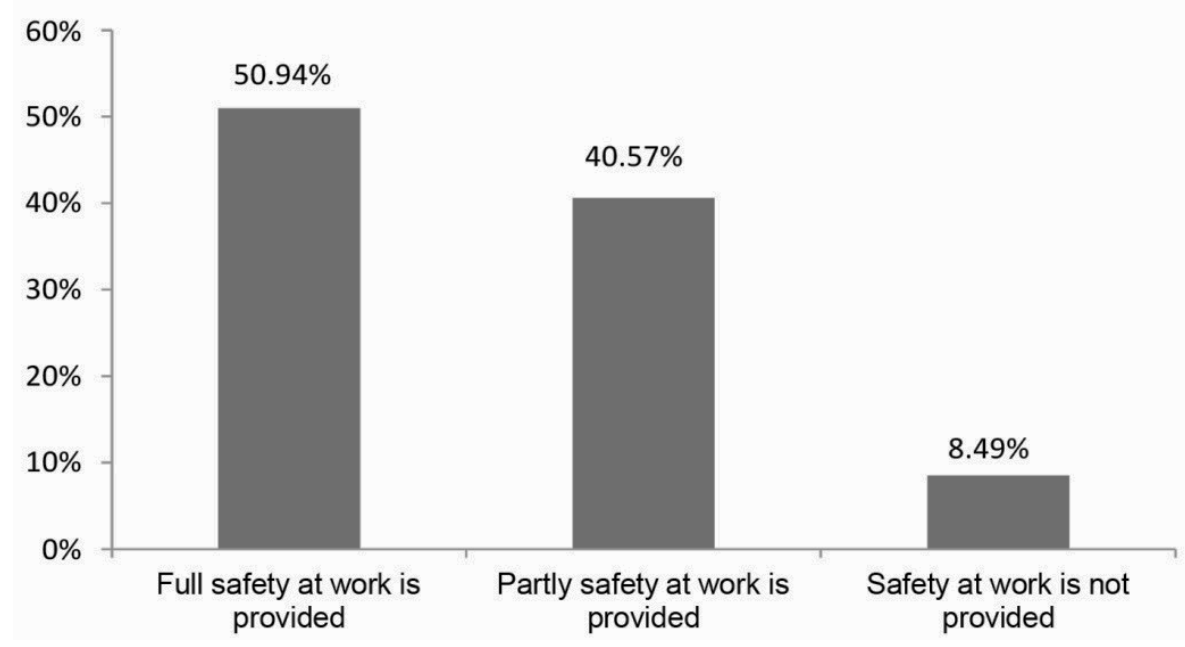

Source: Authors' work

In our first hypothesis we tested if there are differences between men and women in undeclared work stated. The participants were divided into two groups only based on gender. Due to it, we used an independent t-test to test our first hypothesis. Due to independent t-test results, the siginificance level is 0.924 which is higher than 0.05 ; therefore, we conclude that there are no significant differences between women and men and their level of undeclared work stated. Likewise, we tested if gender influences participant's reasons for accepting undeclared work. As per the results given, the significance level is 0.962 which is higher than 0.05 , we conclude there are no gender differences regarding the reason for accepting undeclared work.

Table 4. Differences between men and women in undeclared work stated

\begin{tabular}{|c|c|c|c|}
\hline Independent t-test & $\mathrm{t}$ & $\mathrm{df}$ & $\mathrm{p}$-value \\
\hline Undeclared work & -0.096 & 104 & 0.924 \\
\hline Reason for undelacred work & 0.047 & 104 & 0.962 \\
\hline
\end{tabular}

Source: Authors' work

In our second hypothesis, we tested if there are differences between people from different educational levels and their level of undeclared work, and their reason for accepting undeclared work. The survey 
participants were divided into five groups based on their educational level (primary school, secondary school, higher education school, university Bachelor's degree, and university education Master's degree or higher). Due to more than two groups of participants, we have used the ANOVA test to test our second hypothesis. As perthe results given, we conclude that there are significant differences between people with different educational level and their undeclared work level. However, there are no significant differences between people of different educational levels and their reason for accepting undeclared work.

Table 5. Differences between participants from different educational level and their levelof undeclared work and their reason for accepting undeclared work

\begin{tabular}{|c|c|c|c|c|c|}
\hline Undeclared work & df & $\begin{array}{c}\text { Sum of } \\
\text { squares }\end{array}$ & $\begin{array}{c}\text { Mean } \\
\text { squares }\end{array}$ & $\mathrm{f}$ & p-value>f \\
\hline Model & 2 & 8.84 & 4.42 & 3.56 & 0.032 \\
\hline Error & 103 & 127.887 & 1.242 & & \\
\hline Corrected Total & 105 & 136.726 & & & \\
\hline Reason for undeclared work & \multicolumn{5}{|l|}{} \\
\hline Model & 6 & 13.274 & 2.212 & 1.774 & 0.112 \\
\hline Error & 99 & 123.453 & 1.247 & & \\
\hline Corrected Total & 105 & 136.726 & & & \\
\hline
\end{tabular}

Source: Authors' work

In our hypothesis three, we tested if there are differences between the participant of different ages and their level of undeclared work, and their reason for accepting it. As per ANOVA test results, there are no significant differences between participants of different ages and their level of undeclared work. Likewise, age does not influence their reason for accepting undeclared work. 
Table 6. Differences between participants of different age and their level of undeclared work and their reason for accepting undeclared work

\begin{tabular}{|c|c|c|c|c|c|}
\hline Undeclared work & $\mathrm{df}$ & Sum of squares & $\begin{array}{c}\text { Mean } \\
\text { squares }\end{array}$ & $\mathrm{f}$ & $\mathrm{p}$-value>f \\
\hline Model & 2 & 0.922 & 0.461 & 0.583 & 0.56 \\
\hline Error & 103 & 81.417 & 0.79 & & \\
\hline Corrected Total & 105 & 82.34 & & & \\
\hline Reason for undeclared work & 6 & 4.957 & 0.826 & 1.057 & 0.394 \\
\hline Model & 99 & 77.382 & 0.782 & & \\
\hline Error & 105 & 82.34 & & & \\
\hline Corrected Total & & & &
\end{tabular}

Source: Authors' work

In our last hypothesis we tested if there are differences between participant from different sector (public sector, private sector-domestic company, private sector-foreign company, and non-profit sector) and their level of undeclared work, and their reason for accepting undeclared work. As per results from the ANOVA test, there are no significant differences between employees from different sectors and their level of undeclared work, which also applies to their reason for accepting it.

Table 7. Differences between participants from different sector and their level of undeclared work and their reason for accepting undeclared work

\begin{tabular}{|c|c|c|c|c|c|}
\hline Undeclared work & $\mathrm{df}$ & Sum of squares & Mean squares & $\mathrm{f}$ & $\mathrm{p}$-value>f \\
\cline { 1 - 6 } Model & 2 & 2.194 & 1.097 & 1.632 & 0.200 \\
\hline Error & 103 & 69.212 & 0.672 & & \\
\hline Corrected Total & 105 & 71.406 & & & \\
\hline Reason for undeclared work & \multicolumn{5}{|l}{} \\
\hline Model & 6 & 4.515 & 0.753 & 1.114 & 0.360 \\
\hline Error & 99 & 66.89 & 0.676 & & \\
\hline Corrected Total & 105 & 71.406 & & & \\
\hline
\end{tabular}

Source: Authors' work 


\section{CONCLUSION}

Based on the obtained results of our survey conducted in 2020, discrimination at work in Serbia (33\%) is higher than discrimination during the recruitment process (25\%). The most frequent type of discrimination among employees in Serbia is discrimination based on social status. Regarding safety at work, only half of employees stated that they have full safety at work. The main reason for undeclared work in Serbia is high risk of unemployment. As per our hypothesis tested, there are no gender differences in the level of undeclared work stated and the reason for accepting the undeclared work in Serbia. However, there are significant differences between employees with different educational levels in Serbia and their level of undeclared work. There are no significant differences between employees of different educational levels and their reason for accepting undeclared work. In our research, we also concluded that there are no significant differences between employees of different ages in Serbia and their level of undeclared work, and their reason for accepting undeclared work. Finally, we concluded that there are no significant differences between employees from different sectors in Serbia and their level of undeclared work and their reason for accepting it.

\section{REFERENCES}

1. Avlijaš, S., Ivanović, N., Vladisavljević M., \& Vujić, S. (2013). Gender Pay Gap in the Western Balkan Countries: Evidence from Serbia, Montenegro and Macedonia. FREN - Foundation for the Advancement of Economics, p. 10.

2. Bakić, S. (2009). Tržište kapitala u Srbiji. Oditor, 5(3), pp. 53-64. doi:10.5937/Oditor1903053B

3. Blunch, N., \& Sulla, V. (2011). The Financial Crisis, Labor Market Transitions and Earnings: A Gendered Panel Data Analysis for Serbia. IZA Discussion Paper No. 6151, Available at SSRN: https://ssrn.com/abstract=1968102.

4. Fodor, E., \& Glass, G. (2018). Labor Market Context, Economic Development, and Family Policy Arrangements: Explaining the Gender Gap in Employment in Central and Eastern Europe. Social 
Forces, Volume 96, Issue 3, March 2018, pp. 1275-1302, https://doi.org/10.1093/sf/sox080

5. Goldin, C. (1990). Understanding the Gender Gap: An Economic History of American Women. Oxford University Press.

6. Kostandinović I., \& Stanković, S. (2020). The analysis of the regional disproportions in the labor market in the Republic of Serbia. Ekonimika. vol. 66 (1), pp. 25-35.

7. Kolin, M. (2010). Gender Inequalities and the Status of Women in the Labor Marketin Transitional Serbia. Anthropology of East Europe Review. Bloomington Vol. 28, Iss. 1, pp. 119-137.

8. Kogan, I. (2011). When informal is normal... On the role of credentials and contacts for the job entry in Serbia. Research in Social Stratification and Mobility. Volume 29, Issue 4, December 2011, pp. 445-458.

9. Koettl, J. (2013). Does Formal Work Pay in Serbia? The Role of Labor Taxes and Social Benefit Design in Providing Disincentives for Formal Work. In book: Poverty and Exclusion in the Western Balkans: New Directions in Measurement and Policy,pp. 133-154.

10. Reva, A. (2012). Gender Inequality in the Labor Market in Serbia. World Bank Policy Research Working Paper No. 6008, Available at SSRN: https://ssrn.com/abstract=2027301

11. Rennoy, P. (2007). Undeclared work: a new source of employment? International Journal of Sociology and Social Policy. Vol. 27 No. 5/6, pp. 250-256.

12. Savković, M., \& Gajić, J. (2016). Youth in the contemporary labour markets: A comparison of European Union and Serbia. Sociologija, Volume 58, Issue 3, pp. 450- 466.

13. Schneider, F., \& Williams, C. (2013). The Shadow Economy. London: Institute of Economic Affairs.

14. Vossenberg, S. (2013). Women Entrepreneurship Promotion in Developing Countries: What explains the gender gap in entrepreneurship and how to close it? Maastricht School of Management, Working Paper No. 2013/08.

15. Williams, C. (2016). Developing a Holistic Approach for Tackling Undeclared Work. Background Paper for the European Platform on Tackling Undeclared Work Seminar, Brussels. 
16. Williams, C., \& Franic, J. (2015). Tackling the propensity towards undeclared work: some policy lessons from Croatia. The South East European Journal of Economics and Business, 10 (1), pp. 18-31.

\title{
TRŽIŠTE RADA U SRBIJI - PROBLEM NEREGISTROVANOG RADA
}

\author{
Teodora Šutaković
}

\section{Danka Simović}

Sažetak: Fokus našeg istraživanja je problem neregistrovanog rada na tržištu rada u Srbiji. U radu smo istraživale koliko je učestao neregistrovani rad u Srbiji i koji su glavni uzroci istog. Takođe, testirale smo razlike između različitih grupa zaposlenih $i$ nivoa njihovog neregistrovanog rada, kao i razloga za njihov pristanak na neregistrovani rad. Istraživanje je zasnovano na anketi izvršenoj $u$ Republici Srbiji 2020. godine. Podaci dobijeni putem ankete su obrađeni uz pomoć deksriptivne statistike, t-testova $i$ analize varijanse (ANOVA).

Ključne reči: tržište rada / neregistrovani rad. 